\title{
Concomitant bacteria in the blood of malaria patients in Owerri, southeastern Nigeria
}

\author{
C.N. UKAGA ${ }^{1 *}$, C.N. ORJI ${ }^{1}$, S. OROGWU ${ }^{1}$, B.E.B. NWOKE ${ }^{1}$, J.C. ANOSIKE ${ }^{1}$, \\ O.S. UDUJIH ${ }^{2}$, P.I.K. ONYEKA ${ }^{1}$ and N.C. AWUJO ${ }^{2}$, \\ Imo State University, Department of Animal and Environmental Biology, Oweri, Nigeria \\ Imo State University, Department of Microbiology/Industrial Microbiology, Oweri, Nigeria
}

\begin{abstract}
The presence of concomitant bacteria was assessed in the blood of 125 malaria positive patients and 60 malaria negative controls, resident in Owerri, southeastern Nigeria. Blood samples were cultured in MacConkey, Chocolate and Blood agar, respectively using oxoid signal system after the manufacturer's instructions. Blood cultures of 44 (35.2\%) of the 125 malaria positive patients had bacterial growth while none was observed in the blood cultures of malaria negative patients. The bacteria species identified included: Staphylococcus aureus 4 (3.2\%), Escherichia coli 3 (2.4\%) Salmonella typhi 25 (20\%), Klebsiella pneumoniae 10 (2.4\%) and Pseudomonas aeruginosa 2 (1.6\%). The presence of concomitant bacteria in malaria-positive cases usually results in persistence of malaria-like symptoms after treatment with antimalarials and subsequently taken as resistance of the parasites to the particular drugs in question. The significance of concomitant bacteria in the management of malaria should be given priority.
\end{abstract}

Key words: malaria, bacteraemia, management, Nigeria

Malaria is a debilitating as well as killer disease which affects both the physical and economic well being of people living in endemic areas of Africa (Nebe et al., 2002). More than 300 million people globally are infected with malaria with $90 \%$ of them living in subSaharan Africa, where 1.2 million deaths annually are attributed to the disease (WHO 1993). Malaria is a public health problem in Nigeria. The Nigeria National Malaria Therapy Surveillance report shows high prevalence of the disease $(39.5 \%-75.0 \%)$ as well as varying levels of chloroquine-resistant Plasmodium falciparum malaria from $7 \%$ in the southwestern to $92 \%$ in southeastern Nigeria (Ejezie et al., 1991; Alaribe et al 1994).

Recent studies have shown the existence of concomitant bacterial infections in severe malaria patients, which complicate the manifestation of malaria, thereby confusing diagnosis and chemotherapy especially where they are relatively unknown. Studies have revealed a considerable rate of concomitant bacteria and/or septicaemia or localized bacterial infections of patients with severe malaria (Warrel et al., 1982; Prada et al., 1993). Gram negative bacteria have been implicated as an important cause of septicaemia in some cases of $P$. falciparum malaria infection (Kakkilaya, 2004). Septicaemia presents with violent shaking, chills, and fever, often accompanied by anxiety and rapid breathing, which is similar to the presentations of P. falciparum malaria. Kremsner et al., (1995) observed bacteraemia in African children with severe malaria and emphasized on the need for the inclusion of an antibiotic such as Chlindamycin to the standard quinine treatment.
Falciparum malaria is the most prevalent malaria in southeastern Nigeria (E.N.N. Ezedinachi et al., unpubl.). However, there is very little information on concomitant bacterial infections in severe malaria in Nigeria. This study therefore, aimed at establishing the possible presence of concomitant bacteria infections in malaria positive and apparently healthy patients in Owerri, southeastern Nigeria, as well as to identify the pathogens involved.

A total of one hundred and eighty five (185) persons made up of 125 clinical cases and 60 nonclinical healthy controls were involved in the study. Parasitaemia was established by thick and thin blood smears stained with Giemsa and was categorized into low, moderate and heavy or high. Blood samples were cultured in MacConkey, Chocolate, and Blood agar, respectively using oxoid signal system after the manufacturer's instructions. Isolates from distinct colonies from MacConkey, Chocolate and Blood agar plates were further subjected to bacteriological test (Gram staining) and biochemical tests (coagulase, catalase, oxidase, motility, indole, hydrogen sulphide, citrate utilization and glucose fermentation tests).

Of the 60 apparently healthy controls, 4 (6.7\%) were found infected with malaria parasites in their blood. No bacterial isolate was found in the blood samples. Out of the 125 clinical cases of malaria, a total of $44(35.2 \%)$ also had bacterial infection in their blood. Of the 44 individuals with malaria parasitaemia and bacteraemia, 17 were males and 27 females. The prevalence of the bacteraemia in males and females was $37.8 \%$ and $33.8 \%$, respectively.

\footnotetext{
*Correspondence: Chinyere Ukaga; E-mail:chinyukaga@yahoo.com
} 
Table: 1 Frequency of occurrence of bacterial organisms from the blood culture of malaria positive cases in Owerri, Nigeria $(\mathrm{N}=125)$

\begin{tabular}{lcc}
\hline Bacterial isolate & No. with bacterial isolates & \% bacteraemia \\
\hline Escherichia coli & 3 & 2.4 \\
Klebsiella pneumoniae & 10 & 8.0 \\
Pseudomonas aeruginosa & 2 & 1.6 \\
Staphylococcus aureus & 4 & 3.2 \\
Salmonella typhi & 25 & 20.0 \\
Total & 44 & 35.2 \\
\hline
\end{tabular}

Table 2: Age related frequency of bacteria isolates in the blood of malaria positive cases from Owerri, Nigeria

\begin{tabular}{lccc}
\hline Age & No. examined & No. of infected & \% infected \\
\hline $0-10$ & 42 & 15 & 35.7 \\
$11-20$ & 7 & 0 & 0 \\
$21-30$ & 40 & 6 & 26.1 \\
$31-40$ & 8 & 21 & 52.5 \\
$51-60$ & 3 & 0 & 0 \\
$\geq 61$ & 125 & 1 & 33.3 \\
Total & & 44 & 35.2 \\
\hline
\end{tabular}

Although a large number of females than males were involved in the study, the bacterial isolates occurred more frequently amongst the males. Amongst the different age groups the highest frequency of occurrence of bacterial isolates was found in the age group 31-40 years followed by the youngest age group of children aged 6-10 years (35.7\%) (Table 2).

Each year, more than 10 million African children suffer from severe falciparum malaria, with more than 1 million dying from the disease. Most of these malaria cases are not properly managed due mainly to the fact that therapy is targeted only to the malaria parasites. Similar high frequency of S. typhi in malaria cases has been previously reported among patients in Calabar, Nigeria, an area with drug-resistant malaria (Alaribe et al., 1998). The authors noted that vast majority of cases diagnosed and treated as typhoid were, strictly speaking malaria cases, thereby suggesting the presence of a common factor in malaria and typhoid syndrome.

The findings of this study completely agree with Kremsner et al., (1995) on the need to include an antibiotic in the management of malaria cases. There is also need for proper diagnosis before embarking on treatment. These findings further calls for more extensive research on aspect of malaria case management in order to help reduce the rate of death, especially among young children.

\section{References}

Alaribe, A.A.A., Ejezie G.C. \& Ezedinachi, E.N.N. (1998) The prevalence Salmonella antibody among malaria patients in Calabar. Journal of Medical Laboratory Science 7, 34-41.

Benzerrough, E.H. \& Elom, B. (1991) Malaria Strategies for Africa. World Health Organization, Geneva.

Ejezie G.C., Ezedinach, E.N.U., Usange, A.E., Gemade, E.T.T., Ikpah, N.W. \& Alaribe, A.A.A. (1991) Malaria and its treatment in Rural Aboh Mbaise, Imo State Nigeria. Acta Tropica 48,1724.

Eling, W.M.C. \& Kremsner, P.G. (1994) Cytokines in malaria, pathology and protection. Biotherapy 7, 211-221.

Kakkilaya B.S. (2004) The Malaria Site: Comprehensive Malaria Website. www.malariasite.com

Kremsner, P.G., Radloff P., Metzger, W., Wilding E., Mordumuller B., Philipps J., Jenne, L., Nkeyi, M., Prada, J., Bienzle, U. \& Graninger, W. (1995) Quinine plus clindamycin improves chemotherapy of severe malaria in children. Antimicrobial Agents and Chemotherapy 39 1603-1605.

Nebe, O.J., Adeoye, G.O., Agomuo, P.U. \& Mosanya, M.E. (2002) Malaria in a coastal area of Lagos State, Nigeria: a survey of perceptions and 
practices amongst mothers/caregivers of children under five years old. Nigerian Journal of Parasitology, 23, 61-68.

Nester, E.W., Anderson, D.C., Roberts, C.E., Pearsall, N.N. \& Nester M.T. (2001) Microbiology: A Human Perspective. $3^{\text {rd }}$ Edition. Mc-Graw-Hill Company Inc. New York.

Prada, J., Alabi S.A., Bienzle, N. \& Kremsner, P.G. (1993) Bacterial strains isolated from blood cultures of Nigeria children with cerebral malaria. American Journal of Tropical Medicine and Hygiene 23, 365-369.
UNICEF (1994) Anaemia; Health Systems Development Unit H-01F. The Prescriber UNICEF, USA 11, 1-6.

Warrel, D.A., Looareesuwan, S., Warrel, M.J. Kasemnsarn P., Intaraprasert, R., Bunnag, D. \& Harinasute, T. (1982) Dexamethasone proves deleterious in celebral malaria. New England Journal of Medicine 306, 313-319.

WHO (1993) Tropical Diseases Research Progress (1991-92). World Health Organization, Geneva 